Свидрук I. I.,

irena_svidruk@ukr.net, ORCID ID:0000-0002-3099-6449,

Researcher ID: F-8502-2019,

д.е.н., дои., професор кафедри менеджменту, Львівський торговельно-економічний університет, м. Львів

Клепанчук О. Ю.,

o.klepanchuk@gmail.com, ORCID ID: 0000-0001-7764-614X,

к.е.н., доцент кафедри фінансового менеджменту, Львівський наиіональний університет імені Івана Франка, м. Львів

\title{
ІНСТИТУЦЙНЕ РЕГУЛЮВАННЯ ОКРЕМИХ АСПЕКТІВ ФУНКЦІОНУВАННЯ РИНКУ ПРАЦІ В УКРАЇНІ
}

\begin{abstract}
Анотація. Статтю присвячено виявленню проблемних зон функціонування ринку праці України і окресленню пріоритетів його інституційного регулювання. Аналіз макроекономічних індикаторів дозволив структуровано дослідити п'ятирічну динаміку показників розвитку ринку праиі за рівнями продуктивної, соиіальнокорисної та повної зайнятості, а також фрикиійного, структурного і ичиллічного безробіття. Кількість зайнятого населення у віці 15-70 років у 2019 р. зросла на 217 тис. осіб порівняно з 2018 р. та становила 16,6 млн. осіб. Відповідно, рівень зайнятості зріс у всіх вікових групах. Попри сильні позииї Украӥни в галузі освіти $i$ професійної орієнтації, виявлено значний розрив між кількістю фахівиів та їх ефективною задіяністю у реальних секторах економіки. У 2018-2019 рр. близько половини освіченої молоді працювали не за фахом, а понад 45\% безробітних мають вищу освіту. Виявлено, шьо на ринку праці Украӥни, незважаючи на потужне інституційне втручання, все ще мають місце неформальні трудові відносини, які включають тіньове прачевлаштування та тіньову оплату прачі. Кількість зайнятих у неформальному секторі економіки в 2019 р. скоротилася на 81 тис. осіб порівняно з 2018 р., однак близько 3,5 млн. осіб (19,4\% наявної робочої сили) не реєстрували трудові відносини. Загальний аналіз рівня заробітної плати на ринку праці засвідчив значення його низького рівня для прийняття прачівниками рішення щчодо трудової міграції. Кількість безробітного населення у 2019 р. скоротилася на 91 тис. осіб і становила близько 1,5 млн. осіб. Рівень безробіття скоротився з 8,8\% до 8,2\% 8 усіх регіонах, однак перевищує середні значення у краӥнах Свропейського союзу (6,7\%). Активну політику зайнятості запропоновано розглядати як інструмент сприяння розширеному відтворенню людського капіталу, оскільки ї̈ реалізація передбачає створення робочих місиь та організаџію систем перепідготовки безробітних. У подальшому доиільно розширити дослідження умов функиіонування ринку праиі, систематизувати переваги і недоліки його інституиійного регулювання та визначити необхідність та доцільність державного втручання у окремі аспекти його розвитку.
\end{abstract}

Ключові слова: зайнятість, безробіття, людський капітал, якість життя, інституційне регулювання, суспільне виробництво.

Svydruk I. I.,

irena_svidruk@ukr.net, ORCID ID: 0000-0002-3099-6449,

Researcher ID: F-8502-2019

Doctor of Economics, Associate Professor, Professor of the Department of Management, Lviv University of Trade and Economics, Lviv

Klepanchuk O. Yu., o.klepanchuk@gmail.com, ORCID ID: 0000-0001-7764-614X,

Ph.D., Associate Professor of the Department of Accounting and Taxation, Ivan Franko National University of Lviv, Lviv

\section{INSTITUTIONAL REGULATION OF CERTAIN MANAGEMENT ASPECTS OF LABOR MARKET FUNCTIONING IN UKRAINE}

\footnotetext{
Abstract. The article is devoted to identifying problem areas of the labor market of Ukraine and outlining the priorities of its institutional regulation. The analysis of macroeconomic indicators allowed a structured study of the five-year dynamics of labor market development indicators by levels of productive, socially useful and full employment, as well as frictional, structural and cyclical unemployment. The number of employed people aged 15-70 in 2019 increased by
} 
217 thousands compared to 2018 and amounted to 16.6 million. Accordingly, the employment rate increased in all age groups. Despite Ukraine's strong position in the field of education and professional orientation, there is a significant gap between the number of specialists and their effective involvement in real sectors of the economy. In 2018-2019, about half of educated young people did not work by profession, and more than $45 \%$ of the unemployed have higher education. It was found that in the labor market of Ukraine, despite strong institutional intervention, there are still informal labor relations, which include shadowed employment and shadowed wages. The number of people employed in the informal sector of the economy in 2019 decreased by 81 thousand people compared to 2018, but about 3.5 million people (19.4\% of the available labor force) did not register the employment relationships. The general analysis of the level of wages in the labor market showed the significance of its low level for employees decision making on labor migration. The number of unemployed in 2019 decreased by 91 thousands people and amounted to about 1.5 million. The unemployment rate decreased from $8.8 \%$ to $8.2 \%$ in all regions, but exceeds the average indicators in the European Union (6.7\%). It is proposed to consider active employment policy as a tool to promote the expanded reproduction of human capital, as its implementation involves the creation of jobs and the organization of retraining systems for the unemployed. In the future, it is advisable to expand the study of the labor market conditions, to systematize the advantages and disadvantages of its institutional regulation and to determine the need and feasibility of government intervention in certain aspects of its development.

Keywords: employment, unemployment, human capital, quality of life, institutional regulation, social production.

JEL Classification: E24, E26, J24, J46, J88
DOI: https://doi.org/10.36477/2522-1205-2020-60-03

Постановка проблеми. Метою державного регулювання ринку праці є досягнення ефективної зайнятості громадян для забезпечення зростання рівня якості їх життя, підвищення конкурентоспроможності людських ресурсів, стимулювання їх раціонального розподілу за галузями економіки, забезпечення соціально-трудових гарантій. Разом 3 тим, принципи інституційного невтручання в розвиток економічних процесів у ринковому середовищі зумовлюють особливу роль державних інституцій в регулюванні ринку праці, яка полягає у сприянні, створенні правових, економічних та інституційних умов для забезпечення гідного рівня життя громадян. Отож, ефективна результативність державної політики на ринку праці потребує співучасті в тії виробленні та реалізації усіма зацікавленими сторонами: інститутами працевлаштування, освіти, соціального захисту працівників і роботодавців.

Аналіз останніх досліджень і публікацій. Проблеми розвитку і функціонування ринку праці перебувають у полі наукових інтересів багатьох вітчизняних та закордонних дослідників. В межах проведеного нами дослідження особливу увагу варто звернути на праці К. Бондаревської, А. Аксьонової, які встановили тенденції розвитку i впливу соціально-трудових відносин України за умов глобалізаційних процесів на розвиток ринку праці та запропонували моделі вдосконалення його стану [2]. О. Панькова, О. Касперович визначили та систематизували найбільш суттєві диспропорції соціально-економічного розвитку, які обумовлюються процесами форсованої цифровізації економіки та суспільства [7]. Дослідниками обгрунтовано доцільність використання зон локалізації диспропорцій і пов'язаних з ними ризиків та загроз як пріоритетних сфер розробки й реалізації стратегічно орієнтованої національної економічної політики держави, спрямованої на забезпечення сталого збалансованого розвитку ринку праці України.

В. Близнюк, Я. Юрик присвятили дослідження освітньо-кваліфікаційним особливостям та диспропорціям ринку праці промислового регіону України [1]. Авторами виявлено наявність перекосів у кількісно-якісній структурі ринку праці та посилення невідповідності рівня кваліфікації потребам роботодавців. За результатами аналітичних викладок виокремлено та комплексно охарактеризовано професійне ядро регіону, що охоплює понад $80 \%$ зайнятих за робітничими професіями, в структурі якого сконцентровано наймасовіші види трудової діяльності. Н. Міщук дослідив залежність від рівня освіти динаміки рівня економічної активності, зайнятості та безробіття населення України [6]. Це дозволило автору сформувати сукупність чинників ефективності процесів формування освітнього i трудового потенціалу молоді і визначити елементи освітньо-професійної складової конкурентоспроможності фахівців на ринку праці. У фокусі дослідження Я. Юрика виявлено масштаби, характер змін та детермінанти професійної гендерної сегрегації на ринку праці України, запропоновано напрями вирівнювання гендерних диспропорцій та забезпечення рівних можливостей чоловіків та жінок у сфері праці [9].

G. Liotti, використовуючи модель авторегресивного розподіленого відставання, здійснив аналіз впливу економічної кризи та гнучкості ринку праці на безробіття молоді та дорослих в Італії [11]. L. Novakova проаналізувала вплив технологічного прогресу у виробництві на ринок праці, особливо в умовах заміни працівників автоматизованими системами, що дозволило виявити потенційні загрози для ринку праці Словаччини [12]. C. Aina, G. Casalone досліджували вплив освіти на результати працевлаштування італійських випускників на ринку праці. Запропонована 
науковцями емпірична модель дозволила визначити чітку залежність між тривалістю навчання та матеріальної винагороди від першого робочого місця випускників [10]. D. Saraçoğlu представив результати запроваджених у 2006 р. турецьким урядом жорстких заходів боротьби 3 неформальною працею, які включали інструменти застосування штрафних санкцій без відповідного коригування формальних витрат на оплату праці [13]. Дослідник переконливо доводить: незалежно від примусового застосування інструментів обмеження неформальних трудових відносин капіталізація економіки $\epsilon$ кращим стимулом для легалізації праці.

Отож, представлені наукові дослідження $\epsilon$, беззаперечно, вагомим вкладом у вивчення різних аспектів подолання системних ринкових розривів. Водночас дані наукові праці мають доволі фрагментарний характер, висвітлюючи вузькоспеціалізовані проблемні місця ринку праці.

Постановка завдання. Завданням представленого дослідження $\epsilon$ виявлення проблемних зон функціонування ринку праці України та окреслення пріоритетів його інституційного регулювання.

Виклад основного матеріалу дослідження. Особливість функціонування ринку праці полягає у тому, що ринок робочої сили, ринок праці в Україні на даний час теж перебуває у стадії формування i потребує структурних змін та інституційних реформ, спрямованих на зростання рівня правового захисту працівників, впровадження програм, удосконалення та реалізацію державної політики в сфері зайнятості населення. Ринок праці зазвичай класифікують за різними критеріями та ознаками. Зокрема, за структурною ознакою виділяють ринки праці певних галузей, видів діяльності, форми власності. За критерієм рівня економічного розвитку прийнято поділяти ринок праці на регіональний, однак деякі науковці пропонують групування за рівнем ВВП, оплатою праці чи доходами населення [8]. Територіально ринок праці диференціюють за місцевою, регіональною, національною та міжнародною концентрацією бізнесу. Ще одна класифікація передбачає поділ на потенційний, циркулюючий та внутрішньофірмовий ринок. Демографічний принцип передбачає виокремлення ринків праці молоді, жінок, а також осіб передпенсійного віку та пенсіонерів.

Макроекономічними індикаторами структурованого дослідження ринку праці вважаються рівні зайнятості (табл. 1) та безробіття, при цьому зайнятість прийнято поділяти на продуктивну, соціально корисну або повну. Так, кількість зайнятого населення у віці 15-70 років у 2019 р. зросла на 217 тис. осіб порівняно 32018 р. та становила 16,6 млн осіб. Відповідно, рівень зайнятості зріс у всіх вікових групах. Найвищий рівень зайнятості спостерігається серед осіб $35-50$ років (близько $80 \%$ ), найнижчий - серед осіб $60-70$ років (14\%) та 15-24 роки (31\%).

Основні показники зайнятості населення на ринку праці України у 2010-2019 рр.

\begin{tabular}{|c|c|c|c|c|c|c|c|c|}
\hline \multicolumn{3}{|c|}{ Показники } & 2015 & 2016 & 2017 & 2018 & 2019 & $\begin{array}{c}2019 / \\
2015, \%\end{array}$ \\
\hline \multirow{4}{*}{ 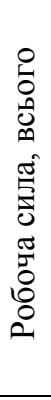 } & \multirow{2}{*}{$\begin{array}{l}\text { у віці } 15- \\
70 \text { років }\end{array}$} & $\begin{array}{c}\text { у середньому, тис. } \\
\text { осіб }\end{array}$ & 18097,9 & 17955,1 & 17854,4 & 17939,5 & 18066,0 & 99,8 \\
\hline & & $\begin{array}{c}\text { у \% до населення } \\
\text { відповідної вікової } \\
\text { групи } \\
\end{array}$ & 62,4 & 62,2 & 62,0 & 62,6 & 63,4 & 101,6 \\
\hline & \multirow{2}{*}{$\begin{array}{c}\text { праце- } \\
\text { здатного } \\
\text { віку }\end{array}$} & $\begin{array}{c}\text { у середньому, тис. } \\
\text { осіб }\end{array}$ & 17396,0 & 17303,6 & 17193,2 & 17296,2 & 17381,8 & 99,9 \\
\hline & & $\begin{array}{c}\text { у \% до населення } \\
\text { відповідної вікової } \\
\text { групи }\end{array}$ & 71,5 & 71,1 & 71,5 & 72,7 & 74,0 & 103,5 \\
\hline \multicolumn{9}{|c|}{ У т.ч. } \\
\hline \multirow{4}{*}{ 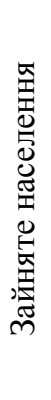 } & \multirow{2}{*}{$\begin{array}{l}\text { У віці } 15- \\
70 \text { років }\end{array}$} & $\begin{array}{c}\text { у середньому, тис. } \\
\text { осіб }\end{array}$ & 16443,2 & 16276,9 & 16156,4 & 16360,9 & 16578,3 & 100,8 \\
\hline & & $\begin{array}{c}\text { у \% до населення } \\
\text { відповідної вікової } \\
\text { групи }\end{array}$ & 56,7 & 56,3 & 56,1 & 57,1 & 58,2 & 102,6 \\
\hline & \multirow{2}{*}{$\begin{array}{c}\text { праце- } \\
\text { здатного } \\
\text { віку }\end{array}$} & $\begin{array}{c}\text { у середньому, тис. } \\
\text { осіб }\end{array}$ & 15742,0 & 15626,1 & 15495,9 & 15718,6 & 15894,9 & 101,0 \\
\hline & & $\begin{array}{c}\text { у \% до населення } \\
\text { відповідної вікової } \\
\text { групи } \\
\end{array}$ & 64,7 & 64,2 & 64,5 & 66,1 & 67,6 & 104,5 \\
\hline
\end{tabular}

Джерело: побудовано за даними [4] 


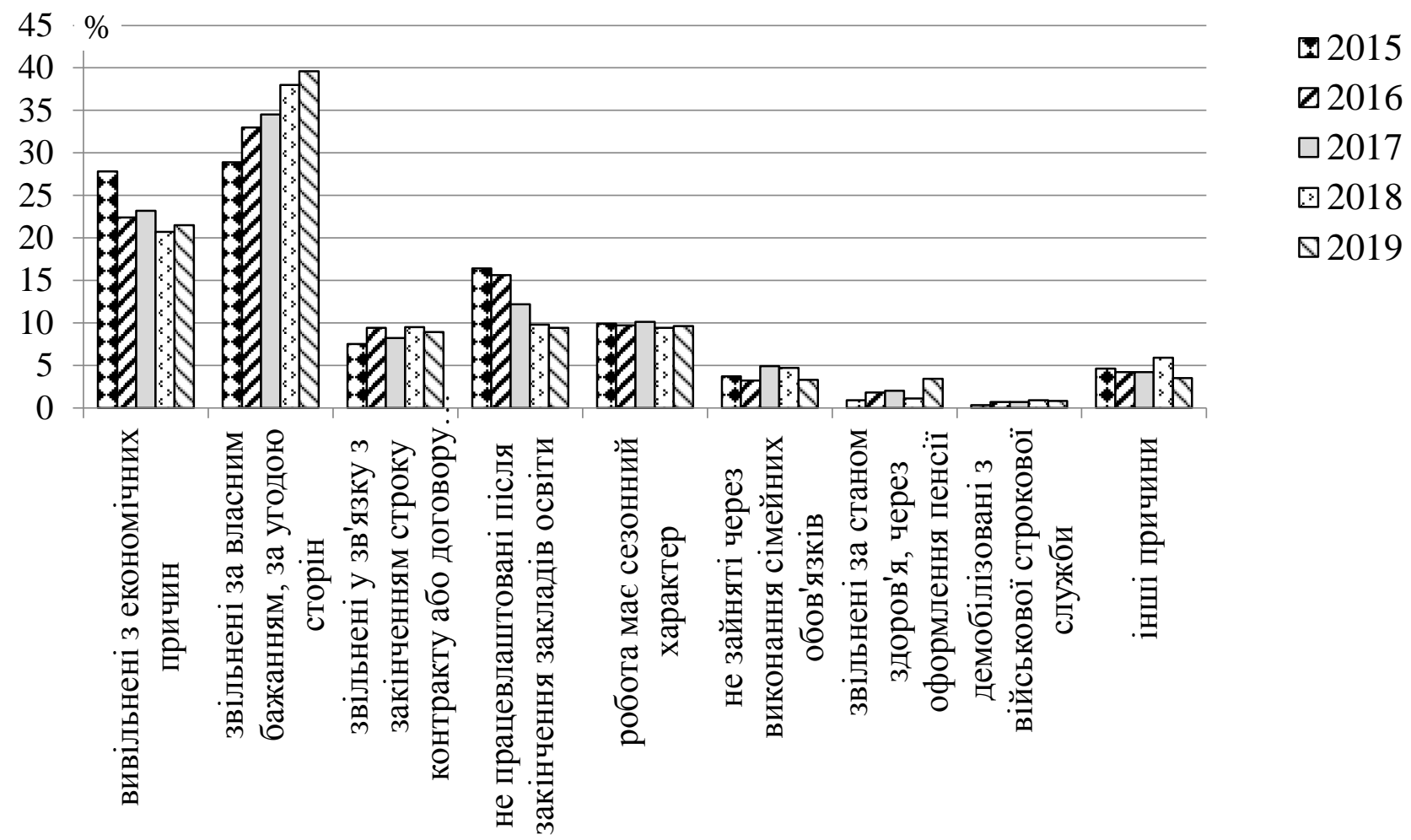

Рис. 1. Основні причини безробіття у 2019 р.

Джерело: побудовано за даними [4]

Говорячи про продуктивну зайнятість, слід мати на увазі, що розвиток людського капіталу охоплює не лише і не стільки процеси накопичення знань, скільки їх практичну реалізацію для ефективного розвитку економіки країни [5]. Дійсно, попри доволі сильні позиції України в галузі освіти i професійної орієнтації, спостерігається значний розрив між кількістю фахівців та їх ефективною задіяністю у реальних секторах економіки. Слід зазначити, що навіть якісне функціонування ринку праці не може беззаперечно гарантувати для молоді забезпечення права на продуктивну зайнятість, адже молоді фахівці зазвичай об'єктивно не здатні конкурувати 3 досвідченими працівниками. Зокрема, у 2018-2019 рр. близько половини освіченої молоді працювало не за фахом, а понад 45\% безробітних мають вищу освіту [3]. I хоча динаміка невлаштування на роботу після навчання як причина безробіття (9,4\% у 2019 р. порівняно з 16,4\% у 2015 р.) свідчить про певне скорочення такого розриву (рис. 1), додатковим негативним чинником впливу на рівень продуктивної зайнятості можна вважати працевлаштування не за отриманим фахом. Не відповідаючи критеріям продуктивної зайнятості, такі громадяни потрапляють до категорії соціально корисно зайнятих, адже вони зайняті у суспільному виробництві. Серед інших представників соціуму, які формують соціально корисну зайнятість, можна виділити військовослужбовців, учнів закладів професійно-технічної освіти та студентів вищих навчальних закладів, а також громадян, зайнятих у домашньому господарстві.
Досліджуючи повну зайнятість, слід зауважити, що на ринку праці України все ще мають місце неформальні трудові відносини. Попри те, що кількість зайнятих у неформальному секторі економіки в 2019 р. і скоротилася на 81 тис. осіб порівняно 3 2018 р., однак, за даними Державної служби зайнятості, близько 3,5 млн осіб $(19,4 \%$ наявної робочої сили) не реєстрували трудові відносини. Найчастіше неформальна зайнятість у 2019 р. виявлялась у сільському господарстві (42\%), торгівлі і ремонті автотранспортних засобів (17\%) та будівництві (17\%). Ця категорія працівників не захищена трудовим законодавством, а отже, не має пенсійного стажу та соціальних гарантій на випадок тимчасової непрацездатності (включаючи догляд за дитиною, допомогу по вагітності та пологах) та безробіття. Попри те, що тіньове працевлаштування часто виступає в ролі своєрідного компенсатора фінансових i соціально-економічних шоків для таких працівників, особливо в середовищі малого бізнесу, слід зауважити, що воно містить значну корупційну складову, а отже вимагає інституційного втручання для подолання цього явища. Для забезпечення детінізації трудових відносин підприємцям було надано право без штрафних санкцій оформити трудові відносини зі всіма працівниками до закінчення 2019 р., завдяки чому було офіційно працевлаштовано близько 64 тис. працівників.

Синхронно 3 питаннями легалізації трудових відносин на ринку праці виступає і проблема легалізації заробітної плати найманих працівників, адже від іiі рівня залежать надходження податку на 
доходи фізичних осіб, що є основним джерелом наповнення місцевих бюджетів, та військового збору.

Загалом попри стабільну тенденцію до зростання, рівень оплати праці в Україні (табл. 2) залишається значно нижчим порівняно 3 сусідніми країнами, що значно послаблює конкурентоспроможність ринку праці і може вважатись одним iз факторів вибору рішення потенційних працівників про трудову міграцію. Ситуація ще більше ускладнюється суттєвими регіональними диспропорціями та галузевою нерівномірністю в оплаті праці.

На нашу думку, важливо оцінювати і такий показник, як ефективна зайнятість, адже він відображає використання трудового потенціалу без втрат. Важливість введення в дослідження поняття ефективної зайнятості обумовлюється іiі потенційно високим впливом на показники людського розвитку. Зазвичай в економічній літературі в це поняття включають повну зайнятість із урахуванням природного безробіття та зайнятість на індивідуальному (внутрішньоорганізаційному) рівні [8]. Активна політика зайнятості може розглядатись в якості суттєвого інструменту вирішення соціальноекономічних проблем суспільства та сприяння розширеному відтворенню людського капіталу. Разом 3 тим, варто зауважити, що реалізація такої політики передбачає насамперед створення робочих місць та організацію систем перепідготовки безробітних, що вимагає значних матеріальних ресурсів. У кризових умовах цей інструмент інституційного регулювання ринку праці може проявлятись як організація масових громадських робіт, що дозволяє створювати додаткові робочі місця без великих обсягів капіталовкладень і дозволяє водночас раціоналізувати використання тимчасово незадіяних трудових ресурсів, забезпечуючи тимчасову зайнятість безробітних. У такому випадку можна стверджувати, що ефективна зайнятість набуває ознак і характеристик соціально корисної, однак не вирішує глобальних проблем безробіття.

Щодо аналізу рівня безробіття (табл. 3), то в економічній практиці зазвичай його диференціюють на фрикційне, структурне та циклічне. Кількість безробітного населення (за методологією МОП) у 2019 р. скоротилася на 91 тис. осіб порівняно з 2018 р. і становила майже 1,5 млн осіб. Відповідно, рівень безробіття скоротився $38,8 \%$ до $8,2 \%$ робочої сили в усіх регіонах. Разом 3 тим, такий рівень безробіття все ще не можна вважати прийнятним, адже він значно перевищує середні значення у країнах Європейського Союзу $(6,7 \%)[4]$.

Таблиця 2

Динаміка середньомісячної заробітної плати штатних працівників* в Україні у 2015-2019 рр.

\begin{tabular}{|c|c|c|c|c|c|c|c|}
\hline \multicolumn{3}{|c|}{ Показник } & 2015 & 2016 & 2017 & 2018 & 2019 \\
\hline \multicolumn{3}{|c|}{$\begin{array}{l}\text { Середньооблікова кількість штатних працівників, тис. } \\
\text { осіб }\end{array}$} & 8065 & 7868 & 7679 & 7661 & 7443 \\
\hline \multirow{3}{*}{$\begin{array}{l}\text { Середньо- } \\
\text { місячна } \\
\text { заробітна } \\
\text { плата }\end{array}$} & \multirow{2}{*}{$\begin{array}{l}\text { номі- } \\
\text { нальна }\end{array}$} & грн & 4195 & 5183 & 7104 & 8865 & 10497 \\
\hline & & $\begin{array}{l}\text { у\% до прожиткового } \\
\text { мінімуму для працездат- } \\
\text { них осіб }\end{array}$ & 304,4 & 323,9 & 403,2 & 461,5 & 499,4 \\
\hline & реальна & у \% до попереднього року & 79,8 & 109 & 119,1 & 112,5 & 109,8 \\
\hline
\end{tabular}

*Дані наведено по юридичних особах із кількістю найманих працівників 10 та більше осіб Джерело: побудовано за даними [4]

Таблиця 3

Показники рівня безробіття на ринку праці України у 2010-2019 рр.

\begin{tabular}{|c|c|c|c|c|c|c|c|c|}
\hline \multicolumn{3}{|c|}{ Показники } & 2015 & 2016 & 2017 & 2018 & 2019 & $\begin{array}{c}2019 / \\
2015 \%\end{array}$ \\
\hline \multirow{4}{*}{ 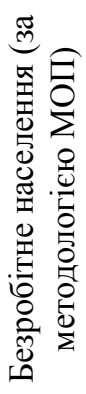 } & \multirow{2}{*}{$\begin{array}{l}\text { у віці } \\
15-70 \\
\text { років }\end{array}$} & $\begin{array}{c}\text { у середньому, тис. } \\
\text { осіб }\end{array}$ & 1654,7 & 1678,2 & 1698,0 & 1578,6 & 1487,7 & 89,9 \\
\hline & & $\begin{array}{c}\text { у \% до населення } \\
\text { відповідної вікової } \\
\text { групи } \\
\end{array}$ & 9,1 & 9,3 & 9,5 & 8,8 & 8,2 & 90,1 \\
\hline & \multirow{2}{*}{$\begin{array}{c}\text { праце- } \\
\text { здат- } \\
\text { ного } \\
\text { віку }\end{array}$} & $\begin{array}{c}\text { у середньому, тис. } \\
\text { осіб } \\
\end{array}$ & 1654,0 & 1677,5 & 1697,3 & 1577,6 & 1486,9 & 89,9 \\
\hline & & $\begin{array}{c}\text { у \% до населення } \\
\text { відповідної вікової } \\
\text { групи }\end{array}$ & 9,5 & 9,7 & 9,9 & 9,1 & 8,6 & 90,5 \\
\hline
\end{tabular}

Джерело: побудовано за даними [4] 
Зазначимо, що рівень безробіття в межах одної економічної системи може бути радикально відмінним у різних демографічних групах. Так, зазвичай зростання цього показника спостерігається у віковій категорії молоді. Так, у 2019 р. в Україні серед громадян 30-34 років спостерігався його найнижчий рівень $(7,3 \%)$, тоді як у віковій категорії до 25 років сягав $15,4 \%$ робочої сили відповідного віку.

Важливість дослідження рівня безробіття обумовлюється насамперед його впливом на рівень доходів населення, а отже на формування платоспроможного попиту на внутрішньому ринку. Крім того, безробіття можна розглядати як негативний фактор впливу на випуск товарів, отож воно здатне зменшувати рівень ВВП.

Фрикційне безробіття (див. рис. 1) може розглядатись як один із чинників значного зростання загального рівня безробіття в Україні. У 2019 р. рівень безробіття, причиною якого визначено звільнення за власним бажанням чи угодою сторін, сягнув $39,6 \%$ (порівняно з 28,9\% у 2015 р.). Оскільки основними причинами фрикційного безробіття $\epsilon$ незадоволення рівнем оплати та умовами праці, його можна вважати відносно короткочасним явищем для особи (в середньому пошуки нової роботи тривають у межах одного місяця), проте висока частка у структурі безробіття може містити значні ризики для стабільності ринку праці.

Відповідно, Державною службою зайнятості України розроблено і впроваджено комплекс заходів для зменшення рівня безробіття. У 2019 р. послугами служби скористалося понад 2,1 млн українців (з них 1 млн мали статус зареєстрованого безробітного), 993 тис. осіб здійснили первинне профілювання (з них 626 тис. осіб - поглиблене профілювання). Кількість працевлаштованих становила 826 тис. осіб, з них 53\% були працевлаштовані без надання статусу безробітного.

Зменшенню кількості безробітних сприяє i практика працевлаштування на новостворені робочі місця з компенсацією роботодавцю витрат у розмірі єдиного внеску на загальнообов'язкове державне соціальне страхування. Завдяки цій програмі було у 2019 р. працевлаштовано 11,4 тис. осіб (з них 4 тис. осіб, недостатньо конкурентоспроможних на ринку праці, та 7,4 тис. осіб, працевлаштованих суб'єктами малого підприємництва). При цьому після працевлаштування для 1,1 тис. осіб здійснювався соціальний супровід за підходом кейсменеджменту.

Структурні диспропорції на ринку праці, які виникають внаслідок стрімкої технологічної перебудови суспільного виробництва, проявляються через зростання розриву між попитом i пропозицією робочої сили щодо професійних або кваліфікаційних характеристик, зумовлюючи зростання рівня структурного безробіття. Для подолання цього явища у 2019 р. Державною службою зайнятості було організовано професійне навчання для понад 139 тис. безробітних. Про ефективність цих заходів свідчить рівень працевлаштування, який після професійного навчання становив $96 \%$.
Феномен циклічного безробіття пов'язаний із циклічними процесами спаду виробництва, в результаті чого спостерігається зниження сукупного попиту на робочу силу. Для згладжування негативних ефектів циклічного безробіття у 2019 р. до громадських робіт тимчасового характеру було залучено близько 200 тис. безробітних.

Висновки i перспективи подальших досліджень у даному напрямі. Аналіз макроекономічних індикаторів дозволив структуровано дослідити п'ятирічну динаміку показників розвитку ринку праці за рівнями продуктивної, соціально корисної та повної зайнятості, а також фрикційного, структурного і циклічного безробіття. Попри сильні позиції України в галузі освіти і професійної орієнтації, виявлено значний розрив між кількістю фахівців та їх ефективною задіяністю у реальних секторах економіки. Виявлено, що на ринку праці України, незважаючи на потужне інституційне втручання, все ще мають місце неформальні трудові відносини, які включають тіньове працевлаштування та тіньову оплату праці. Загальний аналіз рівня заробітної плати на ринку праці засвідчив значення його низького рівня для прийняття працівниками рішення щодо трудової міграції. У подальшому доцільно розширити дослідження умов функціонування ринку праці, систематизувати переваги і недоліки його інституційного регулювання та визначити необхідність та доцільність державного втручання в окремі аспекти його розвитку.

\section{ЛІТЕРАТУРА}

1. Близнюк В. Освітньо-кваліфікаційні диспропорції регіонального ринку праці України / Близнюк В., Юрик Я. // Економіка і прогнозування. 2019. - № 2. - С. 101-119

2. Бондаревська К. В. Особливості розвитку ринку праці України під впливом сучасних глобалізаційних процесів / Бондаревська К. В., Аксьонова А. О. // Причорноморські економічні студії. - 2019. - № 38 (1). - C. 43-47.

3. Державна служба зайнятості України. Аналітична записка щодо ситуації на ринку праці та діяльність Державної служби зайнятості у 2019 році. URL: https://www.dcz.gov.ua/analitics/67(дата звернення: 13.07.2020).

4. Державна служба статистики України. Макроекономічні показники. URL: http://www.ukrstat.gov.ua/ (дата звернення: 13.07.2020).

5. Мельничук Д. П. Продуктивна зайнятість як передумова функціонування знань у формі капіталу / Мельничук Д. П. // Демографія та соціальна економіка. - 2014. - № 2. - С. 135-144.

6. Міщук Н. В. Освіта як чинник конкурентоспроможності молоді на ринку праці / Міщук Н. В. // Інноваційна економіка. -2019. - № 1-2. - С. 80-86.

7. Панькова О. В. Диспропорції соціальноекономічного розвитку в умовах цифровізації: проблеми та ризики для ринку праці України / Панькова О. В., Касперович О. Ю. // Ринок праці та зайнятість населення. - 2019. - № 3(59). - С. 35-43. 
8. Сікерко Л. П. Ефективність зайнятості як чинник людського розвитку / Сікерко Л. П. // Статистика України. - 2009. - № 3. - С. 80-83.

9. Юрик Я. І. Професійна гендерна сегрегація на ринку праці України / Юрик Я. І. // Економіка і прогнозування. - 2019. - № 4. - С. 104-121.

10. Aina C., Casalone G. Early labor market outcomes of university graduates: Does time to degree matter? // Socio-Economic Planning Sciences. -2020. Vol. 71. - Art. 100822.

11. Liotti G. Labour market flexibility, economic crisis and youth unemployment in Italy // Structural Change and Economic Dynamics. - 2020. -Vol. 54. P. 150-162.

12. Novakova L. The impact of technology development on the future of the labour market in the Slovak Republic // Technology in Society. - 2020. - Vol. 62. Art. 101256.

13. Saraçoğlu D. Ş. Do labour market policies reduce the informal economy more effectively than enforcement and deterrence? // Journal of Policy Modeling. - 2020. - Vol. 42, Iss. 3. - P. 679-698.

\section{REFERENCES}

1. Blyzniuk V. and Yuryk Ya. (2019), Osvitn'okvalifikatsijni dysproportsii rehional'noho rynku pratsi Ukrainy, Ekonomika i prohnozuvannia, № 2, s. 101-119

2. Bondarevs'ka, K. V. and Aks'onova, A. O. (2019), Osoblyvosti rozvytku rynku pratsi Ukrainy pid vplyvom suchasnykh hlobalizatsijnykh protsesiv, Prychornomors'ki ekonomichni studii, № 38 (1), s. 43-47.

3. Derzhavna sluzhba zajniatosti Ukrainy. Analitychna zapyska schodo sytuatsii na rynku pratsi ta diial'nist' Derzhavnoi sluzhby zajniatosti u 2019 rotsi, available at: https://www.dcz.gov.ua/analitics/67(data zvernennia: 13.07.2020).

4. Derzhavna sluzhba statystyky Ukrainy. Makroekonomichni pokaznyky, available at: http://www.ukrstat.gov.ua/ (data zvernennia: 13.07.2020).

5. Mel'nychuk, D. P. (2014), Produktyvna zajniatist' iak peredumova funktsionuvannia znan' u formi kapitalu, Demohrafiia ta sotsial'na ekonomika, № 2, s. $135-144$.

6. Mischuk, N. V. (2019), Osvita iak chynnyk konkurentospromozhnosti molodi na rynku pratsi, Innovatsijna ekonomika, № 1-2, s. 80-86.

7. Pan'kova, O. V. and Kasperovych, O. Yu. (2019), Dysproportsii sotsial'no-ekonomichnoho rozvytku v umovakh tsyfrovizatsii: problemy ta ryzyky dlia rynku pratsi Ukrainy, Rynok pratsi ta zajniatist naselennia, № 3(59), s. 35-43.

8. Sikerko, L. P. (2009), Efektyvnist' zajniatosti iak chynnyk liuds'koho rozvytku, Statystyka Ukrainy, № 3, s. 80-83.

9. Yuryk, Ya. I. (2019), Profesijna henderna sehrehatsiia na rynku pratsi Ukrainy, Ekonomika i prohnozuvannia, № 4, s. 104-121.

10. Aina C., Casalone G. (2020), Early labor market outcomes of university graduates: Does time to degree matter? Socio-Economic Planning Sciences, vol. 71, art. 100822 .

11. Liotti G. (2020), Labour market flexibility, economic crisis and youth unemployment in Italy, Structural Change and Economic Dynamics, vol. 54, p. 150-162.

12. Novakova L. (2020), The impact of technology development on the future of the labour market in the Slovak Republic, Technology in Society, vol. 62, art. 101256.

13. Saraçoğlu, D. Ş. (2020), Do labour market policies reduce the informal economy more effectively than enforcement and deterrence? Journal of Policy Modeling, vol. 42, Iss. 3, p. 679-698.

Стаття надійила до редакиії 20 травня 2020 року 